\title{
Synaptic Depression and the Kinetics of Exocytosis in Retinal Bipolar Cells
}

\author{
Juan Burrone and Leon Lagnado \\ Medical Research Council Laboratory of Molecular Biology, Cambridge CB2 2QH, United Kingdom
}

The capacitance technique was used to investigate exocytosis at the ribbon synapse of depolarizing bipolar cells from the goldfish retina. When the $\mathrm{Ca}^{2+}$ current was activated strongly, the rapidly releasable pool of vesicles (RRP) was released with a single rate-constant of $\sim 300-500 \mathrm{sec}^{-1}$. However, when the $\mathrm{Ca}^{2+}$ current was activated weakly by depolarization in the physiological range ( -45 to $-25 \mathrm{mV}$ ), exocytosis from the RRP occurred in two phases. After the release of $20 \%$ or more of the $\mathrm{RRP}$, the rate-constant of exocytosis fell by a factor of 4-10. Thus, synaptic depression was caused by a reduced sensitivity to $\mathrm{Ca}^{2+}$ influx, as well as simple depletion of the RRP. In the resting state, the rate of exocytosis varied with the amplitude of the $\mathrm{Ca}^{2+}$ current raised to the power of 2 . In the depressed state, the sensitivity to $\mathrm{Ca}^{2+}$ influx was reduced approximately

Many synapses exhibit activity-dependent changes in the efficiency of synaptic transmission. A particularly rapid form of synaptic plasticity is depression, which is at least partly caused by a decrease in the number of vesicles that can be rapidly released when $\mathrm{Ca}^{2+}$ channels open (Liley and North, 1953; del Castillo and Katz, 1954; Betz, 1970; Dittman and Regehr, 1998). This "rapidly releasable pool" (RRP) is thought to correspond to the vesicles that are docked to the plasma membrane at the active zone (Burns and Augustine, 1995). A few studies have suggested a second mechanism of synaptic depression: a decrease in the efficiency of exocytosis in response to $\mathrm{Ca}^{2+}$ influx (Furukawa and Matsura, 1978; Korn et al., 1984; Hsu et al., 1996; Bellingham and Walmsley, 1999; Wu and Borst, 1999).

We have investigated exocytosis at the ribbon synapse of depolarizing bipolar cells from the goldfish retina. We find that synaptic depression is caused by a decrease in the efficiency of exocytosis, as well as depletion of vesicles. These two causes of synaptic depression were separated by measuring both the amount of exocytosis and the size of the RRP. The RRP was defined on the basis of capacitance measurements (Mennerick and Matthews, 1996; Sakaba et al., 1997; Gomis et al., 1999; Neves and Lagnado, 1999) and fluorescence measurements (Neves and Lagnado, 1999), which demonstrate that depolarizing bipolar cells contain a finite pool of vesicles that can be completely released within $10-20 \mathrm{msec}$ when the $\mathrm{Ca}^{2+}$ current is activated strongly. An alternative term that has been used to describe this group of vesicles is the "ultrafast pool" (Mennerick and Mat-

\footnotetext{
Received July 9, 1999; revised Oct. 26, 1999; accepted Oct. 28, 1999.

We thank Ana Gomis and Guilherme Neves for discussions of this work.

Correspondence should be addressed to Leon Lagnado, Medical Research Council Laboratory of Molecular Biology, Hills Road, Cambridge CB2 2QH, UK. E-mail: LL1@mrc-lmb.cam.ac.uk.

Copyright (C) 2000 Society for Neuroscience $\quad 0270-6474 / 00 / 200568-11 \$ 15.00 / 0$
}

fourfold. The initial phase of exocytosis accelerated e-fold for every $2.1 \mathrm{mV}$ depolarization over the physiological range and averaged $120 \mathrm{sec}^{-1}$ at $-25 \mathrm{mV}$.

The synapse of depolarizing bipolar cells therefore responds to a step depolarization in a manner similar to a high-pass filter. This transformation appears to be determined by the presence of rapidly releasable vesicles with differing sensitivities to $\mathrm{Ca}^{2+}$ influx. This might occur if vesicles were docked to the plasma membrane at different distances from $\mathrm{Ca}^{2+}$ channels. These results suggest that the ribbon synapse of depolarizing bipolar cells may be a site of adaptation in the retina.

Key words: synapse; vesicle; exocytosis; depression; retina; depolarizing bipolar cell

thews, 1996). Drawing on electron microscopy performed by von Gersdorff et al. (1996), it has been suggested that these vesicles are docked to the plasma membrane under the ribbons (Mennerick and Matthews, 1996; Gomis et al., 1999). An important advantage of depolarizing bipolar cells for the study of synaptic depression is that changes in the size of the RRP that occur after stimulation can be measured relatively directly (Gomis et al., 1999).

We paid particular attention to exocytosis from the RRP when the $\mathrm{Ca}^{2+}$ current was activated weakly, because this is the situation physiologically. The L-type $\mathrm{Ca}^{2+}$ current that controls exocytosis at the synapse of bipolar cells begins to activate at approximately $-45 \mathrm{mV}$ (Tachibana et al., 1993; Burrone and Lagnado, 1997), whereas the depolarizing response to the strongest light does not exceed -30 to $-25 \mathrm{mV}$ (Werblin and Dowling, 1969; Ashmore and Falk, 1980a). The voltage-dependence of exocytosis was steepest at membrane potentials below $-30 \mathrm{mV}$, when the initial rate of release accelerated e-fold for every $2.1 \mathrm{mV}$ depolarization. Surprisingly, exocytosis from the RRP occurred in two phases at these physiological potentials. After the rapid release of $20 \%$ or more of the RRP, the rate-constant of exocytosis from the RRP fell by a factor of 4-10. The major cause of depression at this ribbon synapse was therefore a decreased sensitivity of the exocytic machinery to $\mathrm{Ca}^{2+}$ influx. The time course of exocytosis at physiological potentials appeared to be determined by the presence of rapidly releasable vesicles with differing sensitivities to the activation of the $\mathrm{Ca}^{2+}$ current. This might arise if vesicles comprising the RRP docked to the plasma membrane at different distances from $\mathrm{Ca}^{2+}$ channels. The results suggest that the active zone of depolarizing bipolar cells is a site of adaptation in the retina.

\section{MATERIALS AND METHODS}

Isolated synaptic terminals of depolarizing bipolar cells from the goldfish retina were obtained by enzymatic dissociation using methods described 

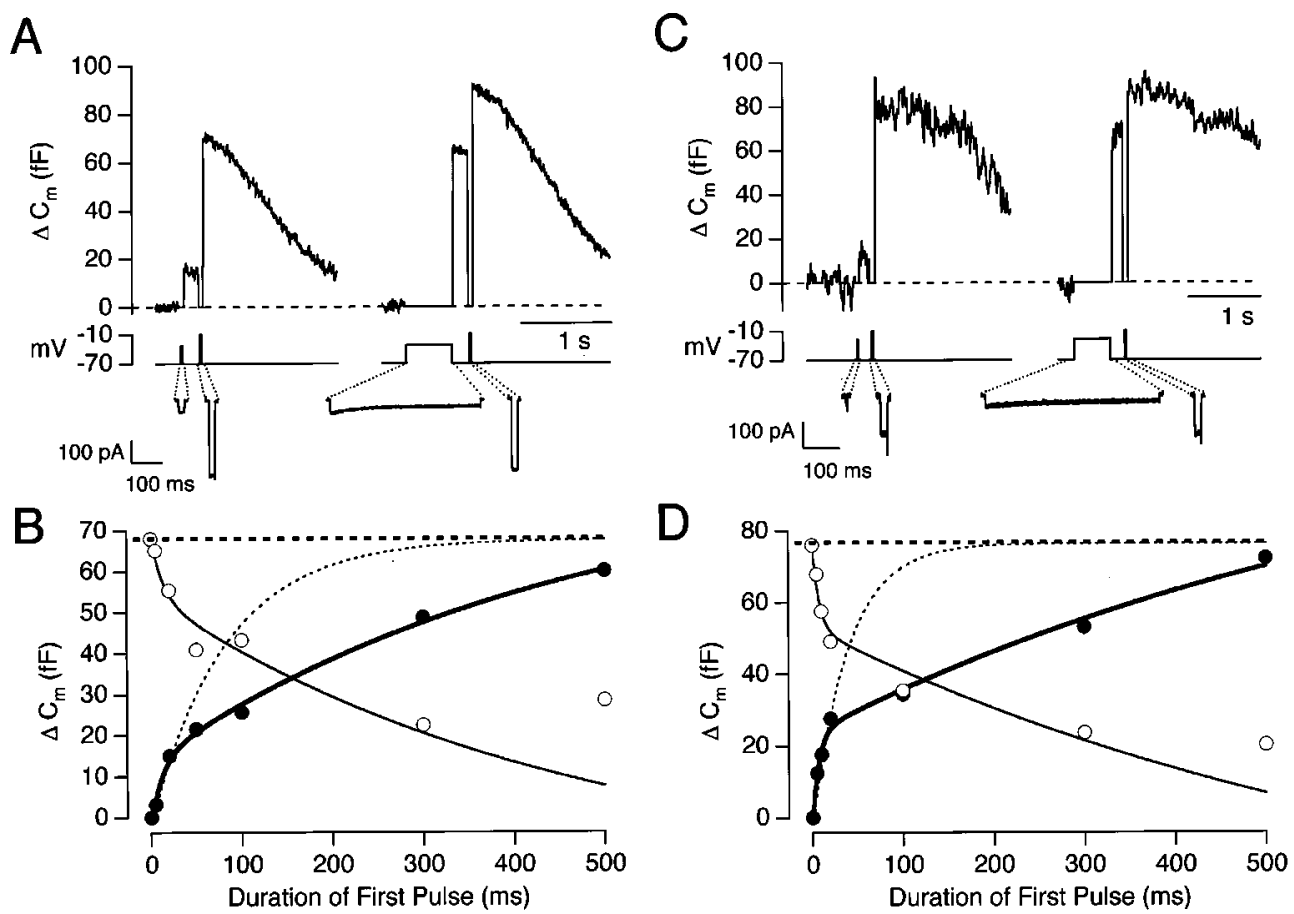

Figure 1. Exocytosis evoked by $\mathrm{Ca}^{2+}$ currents. $A$, Capacitance responses evoked by pairs of depolarizing stimuli. The first stimulus, to $-33 \mathrm{mV}$, had a duration of $20 \mathrm{msec}$ in the left trace and $500 \mathrm{msec}$ in the right trace. In each case, the second stimulus was a $20 \mathrm{msec}$ depolarization to - $10 \mathrm{mV}$, delivered after a delay of $200 \mathrm{msec}$ (the emptying stimulus; see Results). The leak-subtracted $\mathrm{Ca}^{2+}$ currents evoked by each stimulus are shown below on an expanded time scale. $B$, The filled circles plot the size of the capacitance increase as a function of the duration of the depolarization to $-33 \mathrm{mV}$ (same cell as in $A$ ). The bold line through the points is an empirical fit of a double-exponential function, with $14 \mathrm{fF}$ of the capacitance increase occurring with a rate-constant of $77 \mathrm{sec}^{-1}$ and $70 \mathrm{fF}$ with a rate-constant of $2 \mathrm{sec}^{-1}$. The total size of the RRP at the beginning of each stimulus episode, calculated from the summed responses to the shorter stimuli, averaged $68 \mathrm{fF}$ (heavy dashed line). The light dashed line shows the time course of exocytosis that would be predicted if the RRP were exocytosed with a fixed rate-constant of $12 \mathrm{sec}^{-1}$. The open circles plot the capacitance response elicited by the emptying stimulus. The thin line is a mirror image of the bold line. C, Capacitance responses evoked by depolarizations to $-28 \mathrm{mV}$ lasting $5 \mathrm{msec}($ left trace) and $500 \mathrm{msec}$ (right trace). In each case, an emptying stimulus was delivered $200 \mathrm{msec}$ later. $D$, The time course of exocytosis (filled circles) and decline in the size of the RRP (open circles) at a membrane potential of $-28 \mathrm{mV}$ (same cell as in $C$ ). The size of the RRP at the beginning of each stimulus episode averaged $76 \mathrm{fF}$ (heavy dashed line), which is equivalent to 2900 vesicles. The light dashed line shows the time course of exocytosis that would be predicted if the RRP were exocytosed with a fixed rate-constant of $27 \mathrm{sec}^{-1}$. The fit to the filled circles (bold trace) is a double-exponential function with $24 \mathrm{fF}$ occurring with a rate-constant of $140 \mathrm{sec}^{-1}$ and $91 \mathrm{fF}$ with a rate-constant of $1.4 \mathrm{sec}^{-1}$. The thin line describing the decline in the size of the RRP is a mirror image of the bold line.

by Burrone and Lagnado (1997). The standard Ringer's solution contained (in mM): $120 \mathrm{NaCl}, 2.5 \mathrm{CaCl}_{2}, 2.5 \mathrm{KCl}, 1 \mathrm{MgCl}_{2}, 10$ glucose, and 10 HEPES, pH 7.3 .

Terminals were voltage-clamped using the perforated patch technique (Neves and Lagnado, 1999). The solution in the patch pipette contained (in mM): 110 Cs gluconate, $4 \mathrm{MgCl}_{2}, 3 \mathrm{Na}_{2} \mathrm{ATP}, 1 \mathrm{Na}_{2} \mathrm{GTP}, 10 \mathrm{TEACl}$, 0.4 BAPTA, and $20 \mathrm{HEPES}$, with $250 \mu \mathrm{g} / \mathrm{ml}$ nystatin $(260 \mathrm{mOsm}), \mathrm{pH}$ 7.2. Capacitance measurements were not made until the access resistance had fallen below $30 \mathrm{M} \Omega$. The current at the holding potential of $-70 \mathrm{mV}$ was usually -15 to $-40 \mathrm{pA}$. A description of our implementation of the piecewise linear technique (Neher and Marty, 1982) is provided by Neves and Lagnado (1999). Briefly, a sinusoidal command voltage $(50 \mathrm{mV}$ peak-to-peak, $2 \mathrm{kHz}$ ) was superimposed onto a holding potential of -70 $\mathrm{mV}$. The output of the patch-clamp amplifier was analyzed by a hardware lock-in amplifier. The phase of the two orthogonal outputs was set using the "capacitance dither" method, allowing independent measurements of changes in membrane capacitance and conductance (Gillis, 1995). The capacitance signal was calibrated by dithering the whole-cell capacitance compensation by $100 \mathrm{fF}$ at the beginning of each recording episode. The change in capacitance elicited by the stimulus $\left(\Delta C_{\mathrm{m}}\right)$ was measured by subtracting the capacitance signal before the stimulus from that measured after. The "before" measurement was averaged over a period of 20-50 msec, ending $20 \mathrm{msec}$ before depolarization. The "after" measurement was averaged over a period of $20-50 \mathrm{msec}$ beginning $20 \mathrm{msec}$ after repolarization. Neves and Lagnado (1999) found that, after the introduction of a large $\mathrm{Ca}^{2+}$ load, there was a $\mathrm{Ca}^{2+}$-activated tail current, but this conductance change was not large enough to "reflect" onto the capacitance measurement. In this study, the $\mathrm{Ca}^{2+}$ loads and associated conductance changes were considerably smaller. Where capacitance measurements are converted to vesicle numbers, it is assumed that the capacitance of a single vesicle is $26 \mathrm{aF}$ (von Gersdorff et al., 1996; Neves and Lagnado, 1999).

To measure the current-voltage relationship for the L-type $\mathrm{Ca}^{2+}$ current, voltage ramps were applied (from -60 to $+40 \mathrm{mV}$ at 100 $\left.\mathrm{mV} / \mathrm{sec}^{-1}\right)$. Series resistance was compensated $70-80 \%$ with a lag of 10 $\mu \mathrm{sec}$, and the records were leak subtracted.

Measurements are given as mean \pm SEM.

\section{RESULTS}

\section{Fast and slow phases of exocytosis at physiological voltages}

We have investigated exocytosis at the synaptic terminal of depolarizing bipolar cells at membrane potentials at which the $\mathrm{Ca}^{2+}$ current is activated weakly. This is the normal operating condition of this synapse because the L-type $\mathrm{Ca}^{2+}$ current that controls exocytosis begins to activate at approximately $-45 \mathrm{mV}$, whereas the depolarizing response to the strongest light does not exceed -30 to $-25 \mathrm{mV}$ (Werblin and Dowling, 1969; Ashmore and Falk, 1980a). Figure $1, A$ and $B$, shows an experiment designed to measure the time course of exocytosis at a membrane potential of $-33 \mathrm{mV}$. The left side of Figure $1 A$ shows capacitance responses to two depolarizing stimuli delivered $200 \mathrm{msec}$ 
apart from a holding potential of $-70 \mathrm{mV}$. The first stimulus, a 20 msec depolarization to $-33 \mathrm{mV}$, activated the $\mathrm{Ca}^{2+}$ current weakly and elicited a response of $16 \mathrm{fF}$. The second stimulus, a 20 msec depolarization to $-10 \mathrm{mV}$, activated the $\mathrm{Ca}^{2+}$ current strongly and elicited a response of $52 \mathrm{fF}$. This strong stimulus was termed the "emptying stimulus," because it was sufficient to empty the remainder of the RRP (Mennerick and Matthews, 1996; Gomis et al., 1999). The right side of Figure $1 A$ shows a repetition of this protocol in which the duration of the depolarization to $-33 \mathrm{mV}$ was increased to $500 \mathrm{msec}$. The time course of the capacitance increase at $-33 \mathrm{mV}$ is shown by the filled circles in Figure $1 B$ in which two phases of exocytosis are evident. An important aspect of this experiment is that the first phase of release only involved $\sim 20 \%$ of the RRP.

Depletion of the RRP at a membrane potential of $-33 \mathrm{mV}$ is shown by the open circles in Figure $1 B$, which plot the responses to the emptying stimuli. The decline in the size of the RRP mirrored the time course of exocytosis, at least over the first 300 msec, indicating that there was negligible refilling of the RRP on this time scale. A second example of this behavior is shown in Figure 1, $C$ and $D$, which shows the time course of the capacitance increase at a potential of $-28 \mathrm{mV}$. In this terminal, the fast phase of exocytosis involved the release of $\sim 32 \%$ of the RRP. Again, the decline in the measured size of the RRP mirrored the time course of exocytosis over the first $300 \mathrm{msec}$. However, some refilling of the RRP probably occurred at later times. For instance, Figure $1 B$ indicates that the size of the RRP actually increased between 300 and $500 \mathrm{msec}$, although exocytosis continued.

The rate of exocytosis is the time derivative of the capacitance change, so the results in Figure $1, B$ and $D$, indicate that a step depolarization caused a rapid initial burst of exocytosis, followed by a slower phase of release. The synapse of depolarizing bipolar cells therefore has some characteristics of a high-pass filter, signaling most strongly the onset of the stimulus. This initial transient involved a fraction of vesicles in the RRP, and it was followed by exocytosis that was maintained for at least $0.5 \mathrm{sec}$.

\section{The rate-constant of exocytosis from the RRP}

We sought to quantify our measurements in terms that could be related to the properties of exocytosis from the RRP. When the $\mathrm{Ca}^{2+}$ current in bipolar cells is activated strongly, the whole of the RRP is released with a time course that can be described as a single exponential (Mennerick and Matthews, 1996; Gomis et al., 1999). That is, the increase in membrane capacitance $C_{\mathrm{m}}$ is:

$$
\Delta C_{\mathrm{m}}(t)=C_{\max }(1-\exp (-k t)) .
$$

An example of the exponential depletion of the RRP is shown by filled circles in Figure $6 D$. Such a time course indicates a fixed rate-constant of release, $k$, so that at any time the rate of increase in membrane capacitance $C_{\mathrm{m}}$ is related to the remaining size of the RRP (in femtofarads) by:

$$
d C_{\mathrm{m}} / d t=k \cdot R R P(t) .
$$

In the example shown in Figure $1 B$, the rate of capacitance increase at $-33 \mathrm{mV}$ averaged $750 \mathrm{fF} / \mathrm{sec}$ over the first $20 \mathrm{msec}$ of stimulation. Over this period, the size of the RRP averaged $\sim 61$ $\mathrm{fF}$ (measured using the emptying stimuli). So, applying Equation 2 , the rate-constant of release at the start of the stimulus was 12 $\mathrm{sec}^{-1}$. The dashed curve in Figure $1 B$ shows the time course of exocytosis that would be expected if the whole of the RRP were

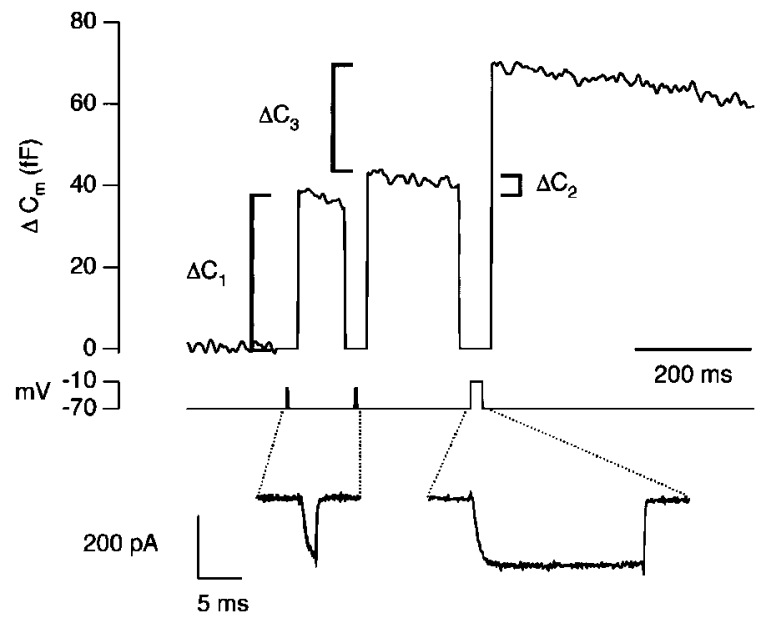

Figure 2. Measuring changes in the efficiency of exocytosis. Increases in membrane capacitance in response to a pair of stimuli that activated the $\mathrm{Ca}^{2+}$ current submaximally. The stimuli were $2 \mathrm{msec}$ depolarizations to $-25 \mathrm{mV}$, with an interval of $100 \mathrm{msec}$. The $\mathrm{Ca}^{2+}$ currents are shown superimposed. In each case, $\mathrm{Ca}^{2+}$ influx carried $0.25 \mathrm{pC}$ of charge. The first response, $\Delta C_{1}$, was $37 \mathrm{fF}$, and the second response, $\Delta C_{2}$, was $4 \mathrm{fF}$. The remainder of the rapidly releasable pool of vesicles was exhausted with a third stimulus, a $20 \mathrm{msec}$ depolarization to $-10 \mathrm{mV}$. This emptying stimulus passed $4.14 \mathrm{pC}$ of charge and elicited a capacitance increase, $\Delta C_{3}$, of $32 \mathrm{fF}$. After accounting for the reduced size of the RRP, the second response was $21 \%$ of the first, i.e., the efficiency of exocytosis was reduced by $79 \%$ (see Results).

released with this rate-constant fixed, calculated using Equation 1. The actual measurements show that the rate-constant of exocytosis at $-33 \mathrm{mV}$ was not fixed but fell significantly. Applying Equation 2 over the period from 50 to $300 \mathrm{msec}$, the rate-constant of exocytosis averaged $3.4 \mathrm{sec}^{-1}$. In the example shown in Figure $1 D$, the rate-constant of exocytosis declined from 27 to $2.5 \mathrm{sec}^{-1}$ at a membrane potential of $-28 \mathrm{mV}$. Similar behavior was observed in all 15 cells in which the time course of exocytosis was measured at potentials below $-25 \mathrm{mV}$.

The initial rate-constant of exocytosis from the RRP was $\sim 40$ times slower at $-33 \mathrm{mV}$ (Fig. $1 B$ ) than at $-10 \mathrm{mV}$ (Mennerick and Matthews 1996; Sakaba et al., 1997; Gomis et al., 1999; Neves and Lagnado, 1999). The slowing of exocytosis was correlated with the smaller steady-state $\mathrm{Ca}^{2+}$ current at more hyperpolarized potentials (Fig. 7), but it could not be accounted for by the slower activation of the $\mathrm{Ca}^{2+}$ current. At $-33 \mathrm{mV}$, the initial rate-constant of exocytosis was $12 \mathrm{sec}^{-1}$, whereas the $\mathrm{Ca}^{2+}$ current was fully activated in $\sim 3-4 \mathrm{msec}$. At $-25 \mathrm{mV}$, the initial rate-constant of exocytosis was $120 \mathrm{sec}^{-1}$ (see Fig. 7), but the $\mathrm{Ca}^{2+}$ current was almost fully activated in 2 msec (Fig. 2). At $-10 \mathrm{mV}$, however, the initial rate-constant of exocytosis can become limited by the activation kinetics of the $\mathrm{Ca}^{2+}$ current (Mennerick and Matthews, 1996).

When the $\mathrm{Ca}^{2+}$ current was activated submaximally, a doubleexponential function provided an empirical description of the capacitance increase measured after various delays, as shown by the bold lines in Figure $1 B, D$. Such a description might be expected if the RRP, which has been defined by strongly activating the $\mathrm{Ca}^{2+}$ current, was actually composed of two populations of vesicles, released with different rate-constants when the $\mathrm{Ca}^{2+}$ current was activated weakly. However, a second possibility is that all vesicles within the RRP were equivalent at the beginning of the stimulus, but the properties of the release process "adapt- 
ed" with time, causing a fall in the rate-constant of release (Hsu et al., 1996). Our measurements of rate-constants have been made in terms of the whole of the RRP, which can be precisely defined and directly measured using our stimulation protocol, rather than a putative subpopulation of this pool. When the whole of the RRP appeared to be released at a fixed rate (see Fig. 6D), the rateconstant was obtained by fitting Equation 1. When two phases of release were apparent (as in Fig. $1 B, D$ ), we measured rateconstants over defined periods by applying Equation 2. The rate-constant at the start of the stimulus, calculated as in the examples above, was termed the "initial rate-constant." Note that the protocol we used in Figure 1 allowed independent measurement of the amount of exocytosis and the size of the RRP at different delays after the beginning of the stimulus.

\section{Changes in the efficiency of exocytosis}

A decrease in the rate of exocytosis in response to a fixed stimulus is a common form of synaptic plasticity termed "synaptic depression," and at some synapses it is thought to be attributable to a decrease in the number of vesicles available for release (Zucker, 1989; Dittman and Regehr, 1998; Wang and Kaczmarek, 1998). The results in Figure 1 indicate that synaptic depression in depolarizing bipolar cells also has a second cause: a decrease in the probability with which vesicles are released from the RRP. To investigate this contribution to synaptic depression, we used a stimulus protocol designed to measure both paired-pulse depression and depletion of the RRP. In the example shown in Figure 2, the two submaximal stimuli ( $2 \mathrm{msec}$ depolarizations to $-25 \mathrm{mV}$ ) were delivered $100 \mathrm{msec}$ apart. The first response, $\Delta C_{1}$, was $37 \mathrm{fF}$, and the second response, $\Delta C_{2}$, was $4 \mathrm{fF}$. The $\mathrm{Ca}^{2+}$ currents elicited by the stimuli were identical (as shown by the overlay), so the reduction in the second response could not be explained by inactivation of the $\mathrm{Ca}^{2+}$ current. To estimate how much depression was caused by depletion of the vesicles available for rapid release, an emptying stimulus was applied $200 \mathrm{msec}$ after the second pulse. The remainder of the RRP elicited a capacitance increase of $32 \mathrm{fF}$, indicating that profound synaptic depression had occurred, even though there were a large number of vesicles still available for rapid release.

The total size of the RRP at the start of the experiment in Figure 2 was calculated as the sum of the three responses, $\Delta C_{1}+$ $\Delta C_{2}+\Delta C_{3}$. The percentage of the RRP released by the first stimulus $\left(R_{1}\right)$ was then estimated as:

$$
R_{1}=\frac{\Delta C_{1} \times 100}{\left(\Delta C_{1}+\Delta C_{2}+\Delta C_{3}\right)},
$$

which in this case was $51 \%$. The size of the RRP when the second stimulus was applied was calculated as $\Delta C_{2}+\Delta C_{3}$, and the percentage of the RRP released by the second stimulus $\left(R_{2}\right)$ as:

$$
R_{2}=\frac{\Delta C_{2} \times 100}{\left(\Delta C_{2}+\Delta C_{3}\right)},
$$

which in this case was $11 \%$. The efficiency $E$ of the second stimulus compared with the first was calculated as:

$$
E=\frac{R_{2}}{R_{1}} \times 100,
$$

and the percentage decrease in efficiency as $100-E$. Thus, after taking into account changes in the size of the RRP, the second response was $21 \%$ of the first, and the efficiency of exocytosis was reduced by $79 \%$. This method seeks to quantify synaptic depres-
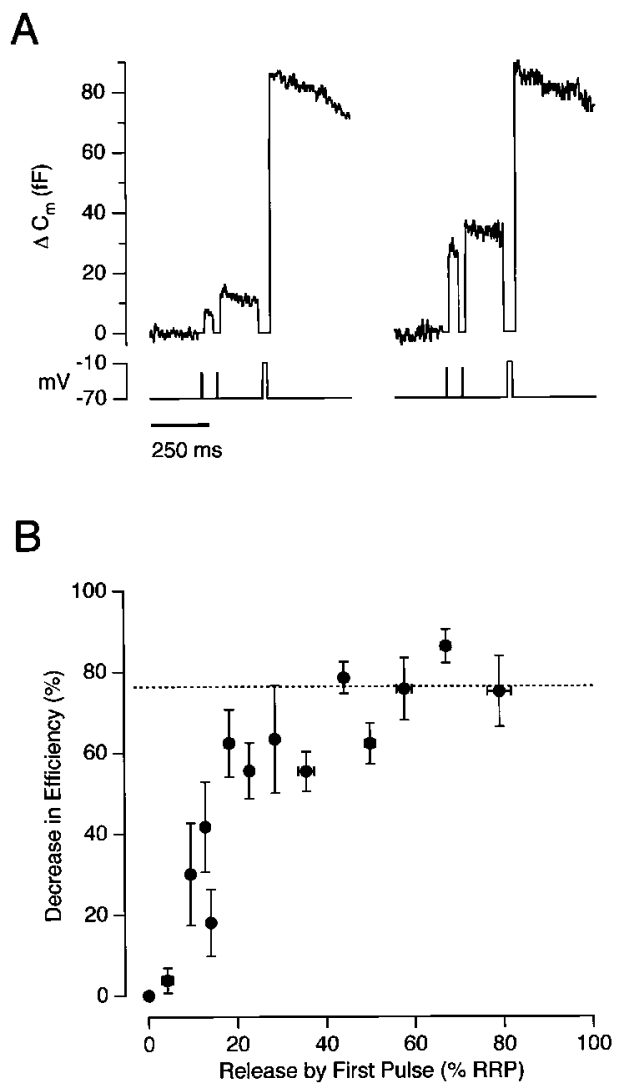

Figure 3. The decrease in the efficiency of exocytosis was dependent on the amount of the RRP released. $A$, Capacitance responses to pairedpulse stimuli lasting $2 \mathrm{msec}$. The left trace shows responses to depolarizations to $-28 \mathrm{mV}$, and the right trace shows responses to depolarizations to $-15 \mathrm{mV}$ from the same terminal. The interval between pulses was 100 msec, and each pair was followed by an emptying stimulus delivered after $200 \mathrm{msec}$. $B$, The relationship between the decrease in the efficiency of exocytosis and depletion of the rapidly releasable pool of vesicles. Results collected from 16 terminals. The paired stimuli were $2-20 \mathrm{msec}$ in duration, and interpulse intervals were 50-200 msec. The decreased efficiency of exocytosis reached a maximal value of $\sim 76 \%$ (dashed line) when $>40 \%$ of the RRP was released.

sion over and above changes in the size of the RRP, but it assumes that there is a negligible supply of new vesicles to the RRP over the period that the measurements are made. The longest interval between the end of the first stimulus and beginning of the third was $350 \mathrm{msec}$, and the results in Figure 1 indicate that there is little refilling over this time scale because the decline in the size of the RRP mirrored the amount of exocytosis (see also Gomis et al., 1999).

The decreased efficiency of exocytosis measured using the double-pulse protocol varied with the amount of the RRP released by the first pulse. Figure $3 A$ shows examples of responses to $2 \mathrm{msec}$ depolarizations to $-28 \mathrm{mV}$ (left trace) and $-15 \mathrm{mV}$ (right trace). The capacitance response to the first pulse to -15 $\mathrm{mV}$ was $27 \mathrm{fF}$, the response to the second was $7 \mathrm{fF}$, and the efficiency was reduced by $64 \%$. The first pulse to $-28 \mathrm{mV}$, on the other hand, elicited a much smaller response of $7 \mathrm{fF}$, and the second pulse elicited a similar response of $6 \mathrm{fF}$, indicating that the efficiency of exocytosis was unchanged. Results from this type of experiment performed on 16 terminals are collected together in Figure 3B, which plots the relationship between the decrease in the efficiency of exocytosis and the percentage of the RRP re- 
A

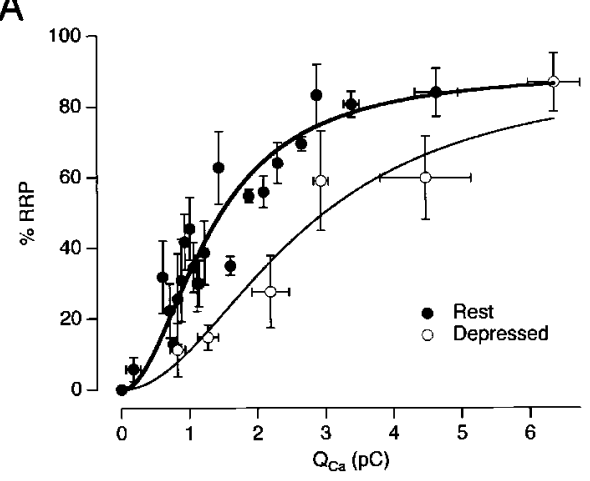

B

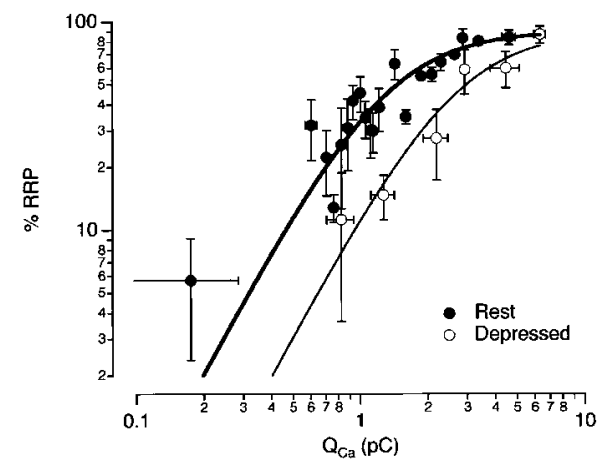

Figure 4. Synaptic depression was associated with a decrease in the $\mathrm{Ca}^{2+}$ sensitivity of exocytosis. $A$, The percentage of the RRP released by a $20 \mathrm{msec}$ stimulus as a function of the integral of the $\mathrm{Ca}^{2+}$ current. The measurements were collected from the type of experiments shown in Figure $3 B$. Each point is the average of four measurements. The filled circles are measurements made from rest. The open circles are measurements made within $200 \mathrm{msec}$ of a conditioning stimulus, which released $>30 \%$ of the RRP. The points were fit with a Hill function $\mathrm{R}=\mathrm{R}_{\max } Q_{\mathrm{Ca}}^{\mathrm{h}} /$ $\left(Q_{1 / 2}^{\mathrm{h}}+Q_{\mathrm{Ca}}^{\mathrm{h}}\right)$, with $h=2, Q_{1 / 2}=1.3 \mathrm{pC}$ for terminals at rest (bold trace), and $2.7 \mathrm{pC}$ for terminals in the depressed state (thin line). $R_{\max }$ was $90 \%$ because $\sim 10 \%$ of the RRP was refilled in the $100-200$ msec interval between the test stimulus and emptying stimulus. $B$, The results from $A$ are plotted on a double-logarithmic scale. The limiting slope was similar at rest and in the depressed state, indicating that there was no significant change in the cooperativity with which $\mathrm{Ca}^{2+}$ activated exocytosis.

leased by the first pulse. The efficiency was reduced by $70-80 \%$ after the release of $\sim 40 \%$ or more of the RRP. These results therefore predict that the rate-constant of exocytosis would, on average, decrease by a factor of $4-5$, which is in agreement with measurements of the kinetics of exocytosis made in Figure 1.

\section{Sensitivity of the exocytic machinery to calcium influx}

Decreases in the efficiency of exocytosis could be characterized as a decrease in the sensitivity of the exocytic apparatus to calcium influx. Figure 4 shows the relationship between the percentage of the RRP released by a $20 \mathrm{msec}$ depolarization and $Q_{\mathrm{Ca}}$, the integral of the $\mathrm{Ca}^{2+}$ current flowing during the stimulus. The filled circles show this relationship measured from rest (that is, from the first response in a paired-pulse protocol of the type shown in Fig. 2). The results could be described by a Hill function of the form, $R=R_{\max } Q_{\mathrm{Ca}}^{\mathrm{h}} /\left(Q_{\mathrm{Ca}}^{\mathrm{h}}+Q_{1 / 2}^{\mathrm{h}}\right)$, where $R$ is the percentage of the RRP released, $R_{\max }$ is the maximum released, $h$ is the Hill coefficient, $Q_{\mathrm{Ca}}$ is the charged carried by $\mathrm{Ca}^{2+}$ influx, and $Q_{1 / 2}$ is the charge carried for half-maximal release. The curve fitted to the points in Figure 4 has $h=2$, indicating that $\mathrm{Ca}^{2+}$ acted cooperatively to stimulate exocytosis, as has been found at other synapses (Dodge and Rahamimoff, 1967; Augustine and Charlton, 1986; Mintz et al., 1995). Release was half-maximal at $Q_{1 / 2}=1.3 \mathrm{pC}$. The open circles in Figure 4 show measurements made when the synapse was depressed and the efficiency of exocytosis reduced to its minimum. These measurements were made from the second response in a paired-pulse protocol in which the first pulse released at least $30 \%$ of the RRP. $Q_{1 / 2}$ increased to $\sim 2.7 \mathrm{pC}$, but there was no obvious change in the degree of cooperativity, as shown by the limiting slopes in a double-logarithmic plot (Fig. 4B). So, for small amounts of calcium influx, the rate of release in the depressed state was reduced by a factor of approximately $(2.7 / 1.3)^{2}$, or $\sim 4.3$-fold.

The results presented above indicate that the RRP is not homogenous. Although it is released with a single rate-constant when the $\mathrm{Ca}^{2+}$ current is activated strongly, weak activation of the $\mathrm{Ca}^{2+}$ current reveals the presence of vesicles with differing sensitivities to $\mathrm{Ca}^{2+}$ influx. One possibility is that vesicles comprising the RRP experience different rises in $\left[\mathrm{Ca}^{2+}\right]$ because they are docked at different distances from $\mathrm{Ca}^{2+}$ channels (see Discussion).

\section{Recovery from synaptic depression}

It has usually been proposed that recovery from synaptic depression reflects refilling of the RRP with new fusion-competent vesicles (Kusano and Landau, 1975; Dittman and Regehr, 1998; Stevens and Wesseling, 1998; Wang and Kaczmarek, 1998), but the interpretation will be more complicated if synaptic depression is also caused by an activity-dependent decrease in the efficiency of exocytosis (Hsu et al., 1996; Bellingham and Walmsley, 1999; Wu and Borst, 1999). Gomis et al. (1999) measured refilling of the RRP in bipolar cells independently of any possible changes in the efficiency of exocytosis by using super-saturating stimuli that always caused complete depletion of the RRP. They found that, after a brief stimulus, $\sim 30 \%$ of the RRP was refilled with a time constant of $\sim 0.6 \mathrm{sec}$ and the remainder with a time constant of $\sim 30 \mathrm{sec}$.

We sought to measure how the efficiency of exocytosis recovered after a stimulus independently of refilling of the RRP. The protocol we used is shown in Figure $5 \mathrm{~A}$. The left side shows that $10 \%$ of the RRP was released by the second of two $20 \mathrm{msec}$ depolarizations to $-26 \mathrm{mV}$, delivered with an interval of 200 msec. The reduction in the efficiency of exocytosis after this short interval was $82 \%$, quantified using the method described above (Fig. 2). When the interval to the second stimulus was increased to $5 \mathrm{sec}$, it released $38 \%$ of the RRP, reflecting an increased efficiency (Fig. $5 A$, right). To quantify the change in the efficiency of exocytosis after this long delay, it was necessary to assume that the first stimulus of the pair released a fixed fraction of the RRP, and this fraction was measured from a trial in which there was a short delay between this first stimulus and the emptying stimulus (Fig. $5 A$, left). Collected results are shown in Figure $5 B$, which plots the decrease in the efficiency of exocytosis for the second stimulus of a pair as a function of the interval between them. Recovery occurred with a time constant of $\sim 6 \sec$ (Fig. $5 B$ ). These measurements can be compared with those made by $\mathrm{Wu}$ and Borst (1999), who found that depression at a giant calyx-type synapse in the auditory brainstem was associated with a reduction in the probability of release from the RRP. Recovery of release probability occurred with a half-time of $\sim 20 \mathrm{sec}$. 

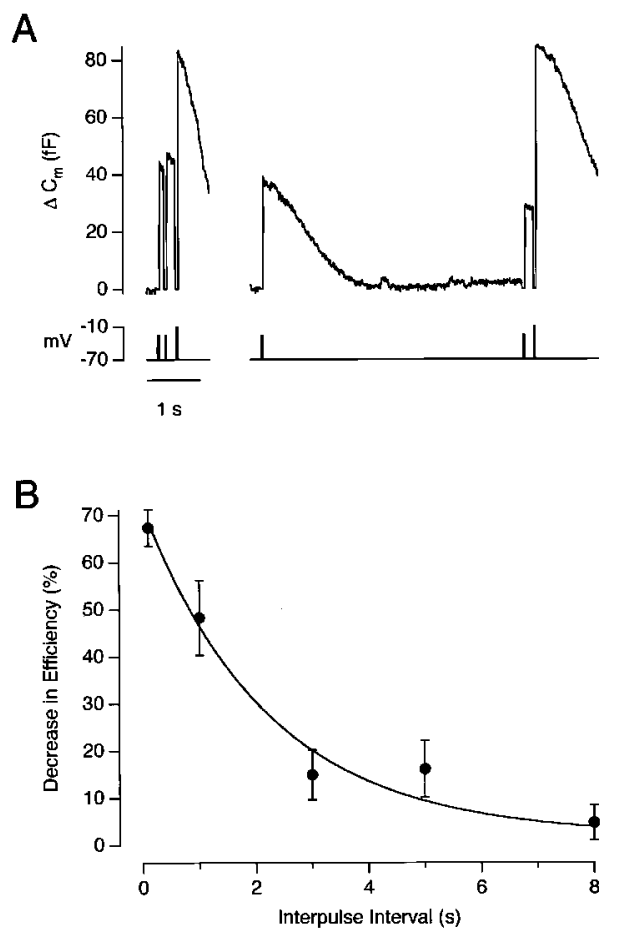

Figure 5. Recovery of synaptic efficiency. $A$, Capacitance responses to a pair of weak stimuli ( $20 \mathrm{msec}$ depolarizations to $-26 \mathrm{mV}$ ) with an interval between pulses of $200 \mathrm{msec}$ (left trace) and $5 \mathrm{sec}$ (right trace). Each pair was followed by an emptying stimulus. $B$, The decrease in efficiency at various intervals after a conditioning stimulus. The submaximal stimulus pairs were all $20 \mathrm{msec}$ in duration, and the membrane potential was selected to cause the first stimulus of the pair to release $40-60 \%$ of the RRP. Points are the average of three to seven measurements. The curve describing the recovery of synaptic efficiency is an exponential with a time constant of $5.8 \mathrm{sec}$.

\section{The voltage-dependence of rapid exocytosis}

The initial phase of exocytosis elicited by submaximal activation of the $\mathrm{Ca}^{2+}$ current was strongly dependent on the potential to which the membrane was stepped. Figure $6, A$ and $B$, compares the time course of the capacitance increase at -30 and $-26 \mathrm{mV}$ in the same cell. The initial rate of exocytosis (in femtofarads per second) was measured by drawing a straight line through the points over short intervals (Fig. $6 B$ ). This quantity was divided by the resting size of the RRP (in femtofarads), measured from the response to the emptying stimulus delivered from rest, to obtain the initial rate-constant of release (Eq. 2). At $-30 \mathrm{mV}$, the rate-constant was $\sim 20 \mathrm{sec}^{-1}$, whereas at $-26 \mathrm{mV}$ it was approximately six times faster.

In the experiments shown in Figure 1, the size of the RRP was relatively constant from trial to trial, as indicated by the fixed amplitude of the summed responses when the test stimulus and emptying stimulus were delivered within $300 \mathrm{msec}$ of each other. More usually, the size of the RRP varied, even with a recovery time of 2 min or more between trials, and there was often a tendency for the size of the RRP to decline during the course of an experiment. To measure the rate-constant of exocytosis when this occurred, we normalized responses to a test stimulus to the size of the RRP measured within the same trial. An example of this approach is shown in Figure 6, $C$ and $D$. The three trials in Figure $6 C$ use the double-pulse protocol to measure the time course of exocytosis at $-35 \mathrm{mV}$. The open circles in Figure $6 \mathrm{D}$ plot the time course of exocytosis at $-35 \mathrm{mV}$, with each response expressed as a percentage of the RRP measured from the summed responses to the test stimulus and emptying stimulus. The initial rate-constant of exocytosis was $37 \mathrm{sec}^{-1}$ at $-35 \mathrm{mV}$. Also shown in Figure $6 D$ are measurements made in the same cell at potentials of -10 and $-38 \mathrm{mV}$, when the initial rateconstants were 385 and $6.6 \mathrm{sec}^{-1}$.

The small error arising from refilling of the RRP in the interval between the test stimulus and emptying stimulus can be seen in Figure $6 D$ in which the filled circles plot results from trials in which the test depolarizations were to $-10 \mathrm{mV}$. The amplitude of the test response saturated at $\sim 92 \%$ of the summed responses, indicating that $\sim 8 \%$ of the RRP was refilled during the $100 \mathrm{msec}$ delay between two emptying stimuli (see also Gomis et al., 1999). Generally, the initial rate-constant of exocytosis was measured using stimuli releasing $<50 \%$ of the RRP, so the errors arising from the supply of new vesicles would be expected to be $<5 \%$.

The initial rate-constant of exocytosis as a function of membrane potential is plotted linearly in Figure $7 A$ and semilogarithmically in Figure $7 B$ (results collected from 16 cells). Between -37 and $-30 \mathrm{mV}$, the rate-constant of exocytosis changed e-fold for every $2.1 \mathrm{mV}$ change in voltage. We were not able to measure capacitance responses to brief stimuli at more hyperpolarized potentials, presumably because the rate of exocytosis was too low. At potentials above $-30 \mathrm{mV}$, the rate of exocytosis was much less steeply voltage-dependent, changing e-fold in $\sim 10 \mathrm{mV}$. At -10 $\mathrm{mV}$, the rate-constant of exocytosis from the RRP was 400-500 $\mathrm{sec}^{-1}$, which is similar to measurements made by Mennerick and Matthews (1996), Sakaba et al. (1997), and Neves and Lagnado (1999).

\section{Calcium acted cooperatively to trigger exocytosis}

Changes in membrane potential modulate the exocytosis of synaptic vesicles through the opening of voltage-dependent $\mathrm{Ca}^{2+}$ channels (Katz and Miledi, 1967; Llinas et al., 1981; Augustine et al., 1985). The $\mathrm{Ca}^{2+}$ current and rate-constant of rapid exocytosis in bipolar cell terminals are compared in Figure $7 A$. The continuous line (corresponding to the right axis) is the voltagedependence of the $\mathrm{Ca}^{2+}$ current measured using ramped changes in membrane potential (see Materials and Methods). When plotted semilogarithmically (Fig. $7 B$ ), it can be seen that the $\mathrm{Ca}^{2+}$ current was less strongly dependent on voltage than the rate of exocytosis over the physiological range of potentials. Whereas the rate-constant of exocytosis changed e-fold in $2.1 \mathrm{mV}$, the amplitude of the $\mathrm{Ca}^{2+}$ current changed e-fold in $6.6 \mathrm{mV}$.

The steep voltage-dependence of exocytosis is probably related to the supralinear relationship between the free $\left[\mathrm{Ca}^{2+}\right]$ and the rate of exocytosis (Augustine and Charlton, 1986; Heidelberger et al., 1994). Assuming that the free $\left[\mathrm{Ca}^{2+}\right]$ at the $\mathrm{Ca}^{2+}$ sensor is linearly related to the amplitude of the $\mathrm{Ca}^{2+}$ current, the results in Figure 6 suggest that $\mathrm{Ca}^{2+}$ activates exocytosis with a cooperativity of $(6.6 / 2.1=) 3.3$, which is similar to the value of 2 measured more directly in Figure 4. A supralinear relationship between exocytosis and $\mathrm{Ca}^{2+}$ influx has also been found at other synapses, with power-laws generally varying between 2 and 4 (Dodge and Rahamimoff, 1967; Augustine and Charlton, 1986; Llinas et al., 1982; Mintz et al., 1995). Perhaps the most direct measurements of the $\mathrm{Ca}^{2+}$-dependence of rapid exocytosis at a synapse made to date are those of Heidelberger et al. (1994), who controlled the free $\left[\mathrm{Ca}^{2+}\right]$ inside the bipolar cell terminal by photolysis of "caged" $\mathrm{Ca}^{2+}$ and measured a cooperativity of 4 . 
Figure 6. Measuring the initial rate of exocytosis. A, Capacitance responses evoked by depolarizations to $-30 \mathrm{mV}$, lasting $10 \mathrm{msec}$ (left), 20 msec (middle), and $100 \mathrm{msec}$ (right). Each stimulus was followed by an emptying stimulus delivered with a delay of $100 \mathrm{msec}$. $B$, The relationship between the size of the capacitance increase and the duration of the depolarization to $-30 \mathrm{mV}$ ( filled circles). The open circles show this relationship at $-26 \mathrm{mV}$ for the same cell. The dashed line shows the average size of the RRP at the beginning of these trials. The initial rates of exocytosis were estimated by drawing a straight line (by eye) over the initial phase of the response. At $-30 \mathrm{mV}$, the rate-constant was $\sim 20 \mathrm{sec}^{-1}$, whereas at $-26 \mathrm{mV}$, the rate-constant was $\sim 120 \mathrm{sec}^{-1}$. C, Capacitance responses evoked by depolarizations to $-35 \mathrm{mV}$, lasting $5 \mathrm{msec}$ (left), $20 \mathrm{msec}$ (middle), and $50 \mathrm{msec}$ (right). D, The time course of exocytosis for depolarizations to $-10 \mathrm{mV}$ (filled circles), $-35 \mathrm{mV}$ (open circles), and $-38 \mathrm{mV}$ (filled squares). The results are expressed as a percentage of the RRP measured from the summed responses to the test stimulus and emp-
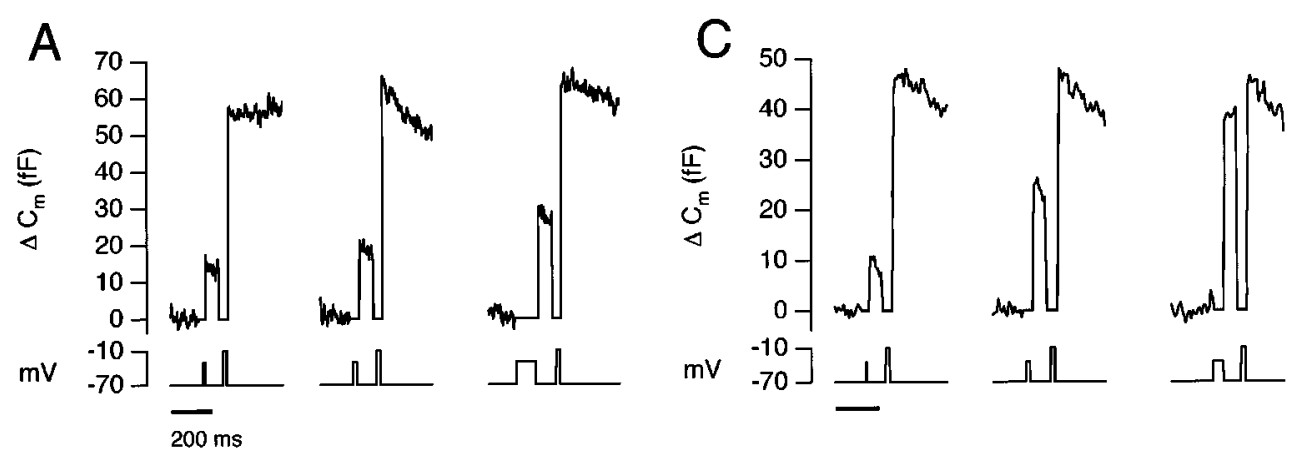

\section{B}

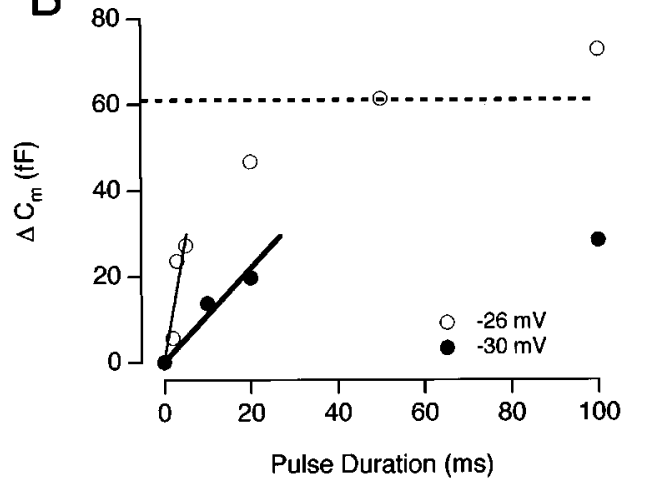

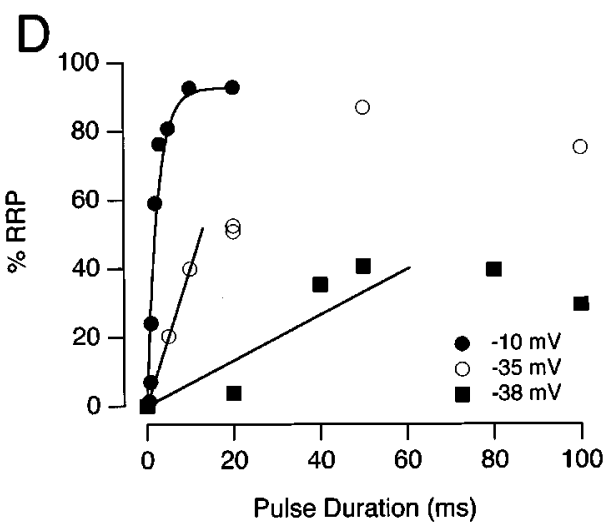

tying stimulus. All measurements from the same cell. The time course of exocytosis at $-10 \mathrm{mV}$ could be described as a single exponential. The rate-constants were 385,37 , and $6.6 \mathrm{sec}^{-1}$ for depolarizations to $-10,-35$ and $-38 \mathrm{mV}$, respectively.

\section{The initial phase of exocytosis}

A clear kinetic distinction between "fast" and "slow" phases of capacitance increase could not be observed during very weak stimulation nor during particularly strong stimulation (when the whole of the RRP appeared to be depleted with a single time constant). To obtain a qualitative understanding of how the rapid output of this synapse might vary, capacitance responses were measured after a $20 \mathrm{msec}$ depolarization to a variety of potentials (Fig. 8A). A duration of $20 \mathrm{msec}$ was used because, when the rapid phase of exocytosis could be distinguished, it was approximately complete within this time (Figs. 1, 6). The amount of exocytosis (expressed as a percentage of the RRP) is plotted as a function of membrane potential in Figure $8 \mathrm{~B}$. An empirical description of these results was obtained by a Hill function of the form $\mathrm{R}=\mathrm{R}_{\max } V^{\mathrm{h}} /\left(V_{1 / 2}^{\mathrm{h}}+V^{\mathrm{h}}\right)$, where $R$ is the $\% \mathrm{RRP}$ released and $V$ is the amplitude of the voltage step above the threshold for activation of the $\mathrm{Ca}^{2+}$ current (taken as $-43 \mathrm{mV}$ for the fit shown). $V_{1 / 2}$, when release was half-maximal, corresponded to a membrane potential of $-33 \mathrm{mV}$. At $-33 \mathrm{mV}$, where the voltagedependence was at its steepest, an extra $6 \%$ of the RRP was released for every $1 \mathrm{mV}$ increase in the amplitude of the depolarization. If the RRP contains 1800 vesicles, this represents the release of an extra 90 vesicles per millivolt.

A notable feature of the results in Figure $8 B$ is that the responses did not saturate until the membrane potential was stepped to approximately $-25 \mathrm{mV}$. This suggests that only the largest voltage signals normally occurring in depolarizing bipolar cells will come close to causing complete exhaustion of the RRP. Over most of the physiological range of membrane potentials, the rapid phase of exocytosis involves only a fraction of the RRP (Figs. 1, 6).

\section{DISCUSSION}

These results indicate that the ribbon synapse of depolarizing bipolar cells adapts to a constant stimulus. A step depolarization elicited a rapid phase of exocytosis, followed by a slow phase that reflected a decrease in the rate-constant of release. Synaptic depression therefore had two causes: depletion of the RRP and a decrease in the efficiency of exocytosis from the RRP. The latter effect was the more important at membrane potentials that cover the operating range in the retina.

\section{The efficiency of exocytosis from the RRP}

A number of studies have suggested that synaptic depression may not be caused simply by depletion of the RRP. Furukawa and Matsura (1978) recorded EPSPs at ribbon synapses between hair cells and eighth nerve fibers in goldfish. A continuous sound caused "adaptive rundown" of successive EPSPs, but even when the response had declined to zero, an increase in sound intensity caused a new discharge. They suggested that release sites in hair cells might have different sensitivities to the amplitude of the depolarization, so that only a few release sites were stimulated by a weak sound but a larger number would respond to a loud sound. Support for this idea was provided by a quantal analysis of changes in the amplitude of EPSPs after changes in sound intensity. An increase in EPSP amplitude was associated with an increase in $n$, the number of vesicles available for release (Furukawa et al., 1978), whereas a decrease in EPSP amplitude was associated with a decrease in $n$ (Furukawa et al., 1982). Qualitatively similar adaptation to a sensory stimulus has been observed in the lateral line organ of fish that responds to vibration (Flock and Russell, 1976). Blight and Llinas (1980) studied transmission at the synapse between "T" fibers from stretch receptors and motoneurons in the crab. They found that strong presynaptic 
A

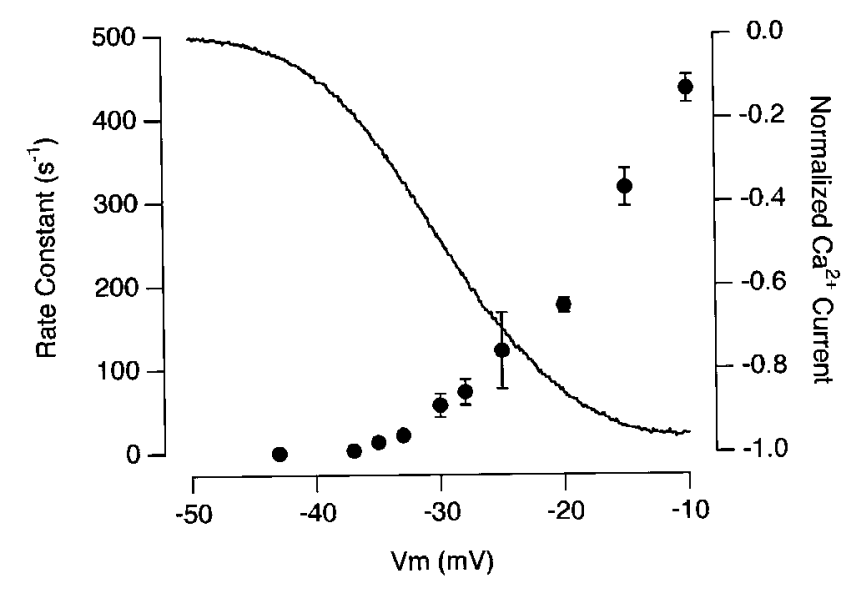

B

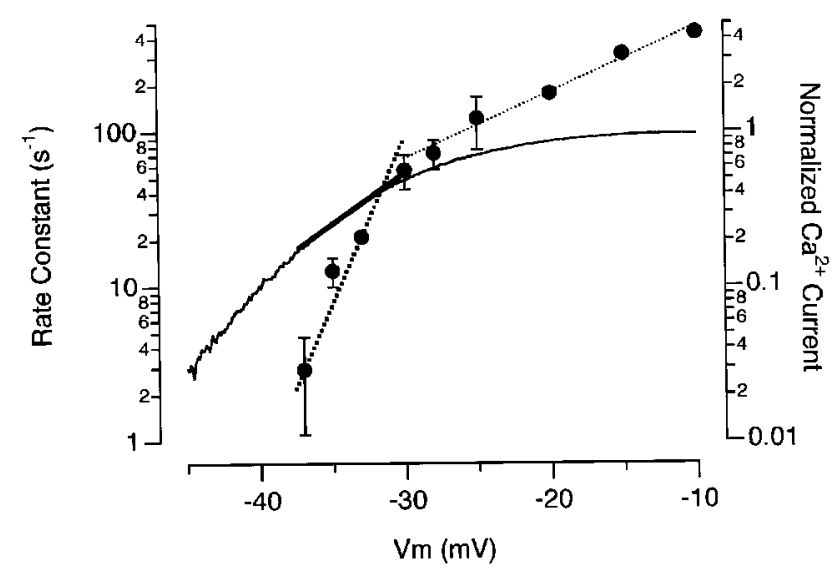

Figure 7. The voltage-dependence of rapid exocytosis. $A$, The initial rate-constant of exocytosis plotted as a function of the membrane voltage (right axis). For membrane potentials ranging from -37 to $-33 \mathrm{mV}$, the initial rate of exocytosis was calculated using a stimulus lasting $20 \mathrm{msec}$ that released $<50 \%$ of the RRP. For membrane potentials from -30 to $-25 \mathrm{mV}$, measurements were made using a stimulus lasting $2 \mathrm{msec}$ that released $<50 \%$ of the RRP. For stronger depolarizations, the rateconstant of exocytosis was calculated from single-exponential fits to the time course of the capacitance increase, as in Figure $6 D$. Each point is the average of measurements on four to eight terminals. The continuous line shows the voltage-dependence of the $\mathrm{Ca}^{2+}$ current, normalized to its maximum. The measurement was made using a ramp change in membrane potential (see Materials and Methods) and is an average from 10 detached terminals. $B$, The results in $A$ plotted semilogarithmically. The rate-constant of exocytosis changed e-fold in $2.1 \mathrm{mV}$ at membrane potentials below $-30 \mathrm{mV}$ (bold dotted line), whereas the $\mathrm{Ca}^{2+}$ current changed e-fold in $6.6 \mathrm{mV}$ over the same range (bold line). Between -30 and $-10 \mathrm{mV}$, the rate-constant of exocytosis changed e-fold in every 10 $\mathrm{mV}$ (thin dotted line).

depolarization led to depression of transmission, causing the postsynaptic response to decline after an initial transient. On repolarization, there was a second strong postsynaptic response driven by the calcium tail-current, indicating that the RRP still contained a large number of vesicles.

Changes in the efficiency of exocytosis from the RRP may not be confined to ribbon synapses. At the squid giant synapse, Kusano and Landau (1975) found that increasing the amplitude of the presynaptic depolarization appeared to increase the num-

\section{A}

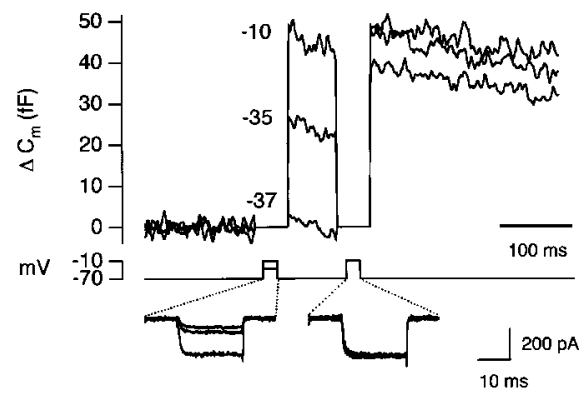

B

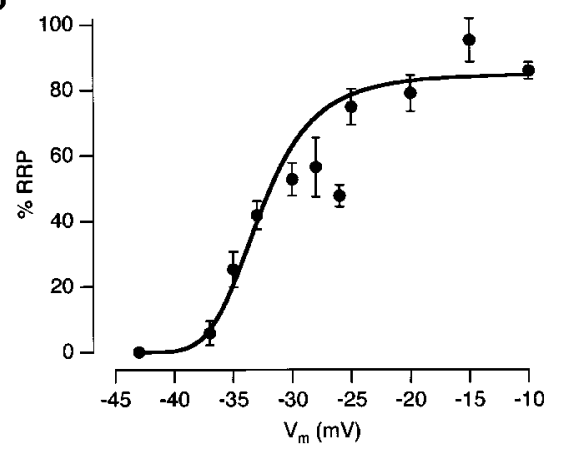

Figure 8. Voltage-dependence of exocytosis for $20 \mathrm{msec}$ pulses. $A, \mathrm{Ca}-$ pacitance increases elicited by $20 \mathrm{msec}$ depolarizations to $-37,-35$, and $-10 \mathrm{mV}$. Each test stimulus was followed by the emptying stimulus. The $\mathrm{Ca}^{2+}$ currents for each stimulus are shown below. $B$, The amount of exocytosis elicited by a $20 \mathrm{msec}$ depolarization to various membrane potentials. Each point is the average of $4-16$ measurements. Results collected from a total of 20 cells. The capacitance increase to the test stimulus was expressed as a percentage of the RRP. The line fitted through the points is a Hill function (see Results).

ber of vesicles available for rapid release. More recently, Wu and Borst (1999) studied a giant calyx-type synapse in the auditory brainstem and found that depression was associated with a reduction in the probability of release from the RRP.

It is interesting to relate the changes in the efficiency of exocytosis that we observed to events at the active zone. Electron microscopy performed by von Gersdorff et al. (1996) indicates that there are $\sim 22$ vesicles docked to the plasma membrane under each ribbon, and it has been suggested that these vesicles comprise the RRP (Mennerick and Matthews, 1996; Gomis et al., 1999). The decrease in the efficiency of exocytosis was halfmaximal after the release of $10-15 \%$ of the RRP (Fig. $3 B$ ), which would correspond to only two to three vesicles per active zone.

\section{Factors that might affect the efficiency of exocytosis from the RRP}

We have considered three possible causes for synaptic depression over and above depletion of the RRP. First, vesicles within the RRP that are docked further away from $\mathrm{Ca}^{2+}$ channels might be released less efficiently than those docked more closely. Second, some vesicles within the RRP might have a lower intrinsic sensitivity to $\mathrm{Ca}^{2+}$ (independent of their location). Third, there might be some form of negative feedback that regulates the $\mathrm{Ca}^{2+}$ sensitivity of exocytosis and causes the rate-constant of exocytosis to fall with a delay.

Full consideration of the first model would require an under- 
standing of the spatial organization of $\mathrm{Ca}^{2+}$ channels and vesicles at the plasma membrane, as well as the properties of the $\mathrm{Ca}^{2+}$ buffers and $\mathrm{Ca}^{2+}$ sensor(s) for exocytosis. However, some simple calculations indicate the feasibility of the idea that vesicles docked at the active zone may not all experience the same $\mathrm{Ca}^{2+}$ signal. In the presence of a mobile buffer, the free concentration of which is relatively constant, the steady-state free $\left[\mathrm{Ca}^{2+}\right]$ near a single $\mathrm{Ca}^{2+}$ channel is expected to fall exponentially with the distance $r$ (Neher, 1998):

$$
\left[C a^{2+}\right]=\frac{i_{\mathrm{Ca}}}{4 \pi F D_{\mathrm{Ca}} r} \exp (-r / \lambda),
$$

where $i_{\mathrm{Ca}}$ is the single channel current, $F$ the Faraday constant, and $D_{\mathrm{Ca}}$ is the diffusion coefficient for free $\mathrm{Ca}^{2+}$. The spatial extent of free $\mathrm{Ca}^{2+}$ will be determined by the space constant $\lambda$, which is a measure of the distance a $\mathrm{Ca}^{2+}$ ion diffuses before it is intercepted by a buffer molecule. $\lambda$ is given by:

$$
\lambda=\sqrt{D_{\mathrm{Ca}} / k_{\text {on }}[B]_{\mathrm{o}}},
$$

where $k_{\text {on }}$ is the rate-constant with which $\mathrm{Ca}^{2+}$ binds the buffer, and $[B]_{\mathrm{o}}$ is the free concentration of buffer. The value for $[B]_{\mathrm{o}}$ is obtained from $[B]_{\mathrm{o}}=B_{\mathrm{t}} K_{\mathrm{d}} /\left(K_{\mathrm{d}} /[\mathrm{Ca}]_{\mathrm{b}}\right)$, where $K_{\mathrm{d}}$ is the dissociation constant for the buffer, $[C a]_{\mathrm{b}}$ is the basal free $\mathrm{Ca}^{2+}$ concentration, and $B_{\mathrm{t}}$ is the total concentration of mobile buffer. At the ribbon synapse of hair cells, there is a mobile $\mathrm{Ca}^{2+}$ buffer, the concentration of which is expected to be 1-2 mM if it binds $\mathrm{Ca}^{2+}$ at a rate similar to BAPTA (Roberts, 1993; Tucker and Fettiplace, 1996). Similarly, the synaptic terminal of depolarizing bipolar cells contains $\sim 1.6 \mathrm{~mm}$ of a BAPTA-like buffer (J. Burrone and L. Lagnado, unpublished observations). The $K_{\text {on }}$ for BAPTA is $6 \times 10^{8} \mathrm{M} / \mathrm{sec}$, which yields a value of $\lambda=17 \mathrm{~nm}$, assuming $D_{\mathrm{Ca}}=220 \mu \mathrm{m}^{2} / \mathrm{sec}$, and $\left[\mathrm{Ca}^{2+}\right]_{\mathrm{b}}=50 \mathrm{nM}$. If four $\mathrm{Ca}^{2+}$ ions act cooperatively to trigger exocytosis (Heidelberger et al., 1994), a fivefold difference in the rate of release would reflect a 1.5 -fold difference in the $\left[\mathrm{Ca}^{2+}\right]$ at the sensor. Such variations in the $\left[\mathrm{Ca}^{2+}\right]$ at the sensor might occur if the separation between the sensor and nearby $\mathrm{Ca}^{2+}$ channels were subject to a variability of only a few nanometers. A vesicle has a diameter of $\sim 36 \mathrm{~nm}$, so it seems possible that vesicles docked at the active zone may have different probabilities of release because the $\mathrm{Ca}^{2+}$ sensor that they are associated with experiences slightly different rises in $\left[\mathrm{Ca}^{2+}\right]$.

The results of two studies suggest that vesicles docked near the ribbons of hair cells may indeed have different sensitivities to $\mathrm{Ca}^{2+}$ influx. First, Roberts (1993) made numerical simulations of the $\left[\mathrm{Ca}^{2+}\right]$ at the ribbon synapse of hair cells, taking into consideration the contribution of all the $\mathrm{Ca}^{2+}$ channels localized to an active zone. The simulations predicted that the profile of the time-averaged $\left[\mathrm{Ca}^{2+}\right]$ near the plasma membrane will vary greatly across the active zone, with peaks of high $\left[\mathrm{Ca}^{2+}\right]$ occurring under single $\mathrm{Ca}^{2+}$ channels (see also Zucker, 1989). Second, electron tomography of these synapses indicates that probably $<50 \%$ of vesicles are docked within $50 \mathrm{~nm}$ of a $\mathrm{Ca}^{2+}$ channel (Lenzi et al., 1999), suggesting that vesicles toward the periphery of an active zone experience a substantially smaller rise in $\left[\mathrm{Ca}^{2+}\right]$ than those toward the center. It remains to be seen whether the arrangement of vesicles and $\mathrm{Ca}^{2+}$ channels at the active zone of hair cells might account for the variable sensitivity to depolarization suggested by Furukawa et al. (1982).

A second possible cause of heterogeneity within the RRP is that different vesicles require different $\mathrm{Ca}^{2+}$ concentrations to trigger their release. Recently, Blank et al. (1998) found that $\mathrm{Ca}^{2+}$ concentrations above threshold caused the fusion of only a subpopulation of secretory vesicles in sea urchin eggs and proposed that individual vesicles have different sensitivities to $\mathrm{Ca}^{2+}$. However, it does not seem likely that this mechanism operates in bipolar cells, given the results of Heidelberger et al. (1994). They used caged $\mathrm{Ca}^{2+}$ to impose spatially uniform rises in free $\left[\mathrm{Ca}^{2+}\right]$ in the synaptic terminal of depolarizing bipolar cells and found that the resulting rise in capacitance always followed a single exponential time course with a fixed final amplitude, indicating that all vesicles within the RRP had a fixed intrinsic sensitivity to $\mathrm{Ca}^{2+}$.

The possibility that the $\mathrm{Ca}^{2+}$ sensitivity of the reaction triggering exocytosis might fall because of some form of negative feedback has been raised by a few studies. Korn et al. (1984) performed a quantal analysis at inhibitory synapses on the Mauthner cell of goldfish and concluded that synaptic depression was caused by a decrease in release probability rather than a decrease in quantal content. They suggested that vesicle fusion caused a transient refractoriness of the exocytic apparatus by disrupting the normal organization of the active zone (Triller and Korn, 1982). Hsu et al. (1996), working on the squid giant synapse, found that the rate of exocytosis elicited by a constant rise in $\left[\mathrm{Ca}^{2+}\right]$ fell with a time constant of $30 \mathrm{msec}$ but could not account for this by depletion of the RRP. They suggested that the exocytic machinery might adapt to the $\mathrm{Ca}^{2+}$ signal and that the site of adaptation might be the $\mathrm{Ca}^{2+}$-sensitive molecule controlling the final step in release. A similar idea has been proposed by Bellingham and Walmsley (1999), who found that synaptic depression at the calyx of Held was modulated by $\mathrm{Ca}^{2+}$ entry.

Our results do not rule out the possibility that the decreased efficiency of exocytosis from the RRP reflects a time-dependent "adaptation" of the exocytic machinery of the type postulated by Hsu et al. (1996). However, in our view, the simplest possibility with the most evidence is that vesicles within the RRP are subject to different rises in $\mathrm{Ca}^{2+}$ concentration because they are different distances from $\mathrm{Ca}^{2+}$ channels.

\section{Operating characteristics of the bipolar cell synapse}

A common feature of neurons possessing ribbon synapses is that they do not fire sodium-dependent action potentials, but instead signal with graded voltage changes that can be as small as a fraction of a millivolt. In the dark-adapted retina, for instance, the absorption of a single photon generates a signal of $\sim 250 \mu \mathrm{V}$ in a depolarizing bipolar cell receiving synaptic inputs from rod photoreceptors (Ashmore and Falk, 1980b). These small signals are reliably transmitted to ganglion cells (Barlow et al., 1971), and this may depend on the steep voltage-dependence of release from bipolar cells. The rate of exocytosis at the terminal of depolarizing bipolar cells was at its steepest at potentials below $-30 \mathrm{mV}$, accelerating e-fold for every $2.1 \mathrm{mV}$ depolarization (Fig. 7). Exocytosis at the ribbon synapse of rods has a similar voltage sensitivity (Attwell et al., 1987; Belgum and Copenhagen, 1988).

The voltage-dependence of exocytosis fell dramatically at potentials above the physiological range (more than $-30 \mathrm{mV}$ ). Matsui et al. (1998) made paired recordings from depolarizing bipolar cells and synaptically connected ganglion cells in the newt retina and also found that synaptic gain decreased dramatically above $-30 \mathrm{mV}$. It therefore seems that the input-output properties of this synapse are matched to the $15-20 \mathrm{mV}$ range in which it normally operates. Other ribbon synapses respond to somewhat smaller voltage signals. For instance, the oscillatory potentials 
that modulate exocytosis from hair cells have a peak-to-peak amplitude of $\sim 10 \mathrm{mV}$ (Crawford and Fettiplace, 1981). The operating range of the rod synapse is only $\sim 5 \mathrm{mV}$ because light causes a hyperpolarization from a dark potential of $-40 \mathrm{mV}$, whereas the $\mathrm{Ca}^{2+}$ current turns off below $-45 \mathrm{mV}$ (Attwell et al., 1987).

Ganglion cells postsynaptic to depolarizing bipolar cells show a variety of behaviors in response to a step of light (Dowling, 1987). Some are purely transient, responding only when the light is turned on. Some are sustained, signaling with similar intensity throughout a step. Others show a mixed transient-sustained response. It seems likely that the transient component of exocytosis that we observe in depolarizing bipolar cells contributes to the transient signals seen in postsynaptic ganglion cells. Our results indicate that this differentiation is performed by a subset of vesicles within the RRP that are particularly sensitive to $\mathrm{Ca}^{2+}$ influx. In the retina, this transformation plays an essential role in the processing of visual signals (Lagnado, 1998). Feedback connections from amacrine cells onto the synaptic terminal of depolarizing bipolar cells will also contribute to the generation of transient output from this synapse (Roska et al., 1998). It seems most likely that the sustained signals that occur in postsynaptic ganglion cells are generated by the slower continuous component of exocytosis that the synapse supports in response to maintained depolarization (Lagnado et al., 1996; Rouze and Schwartz, 1998; Neves and Lagnado, 1999).

Exocytosis from the synaptic terminal of depolarizing bipolar cells has also been studied by detecting glutamate release using glutamate-activated channels in retinal horizontal cells (Sakaba et al., 1997; von Gersdorff et al., 1998). As in the present study, von Gersdorff et al. (1998) applied sustained depolarizations that activated the $\mathrm{Ca}^{2+}$ current to varying degrees. When the $\mathrm{Ca}^{2+}$ current was smaller than $\sim 140 \mathrm{pA}$, the glutamate-activated current in the "sniffer" cell had two peaks separated by delays of 50-200 msec. This was interpreted as indicating two discrete bouts of exocytosis. von Gersdorff et al. (1998) suggested that the first bout corresponded to the RRP (perhaps vesicles docked to the plasma membrane) and the second bout to a reserve pool (perhaps vesicles on the ribbon). It was also suggested that these two phases of release "fused" into one phase that was complete within $100 \mathrm{msec}$ when the $\mathrm{Ca}^{2+}$ current was larger than $\sim 140 \mathrm{pA}$. Using the capacitance technique, we also find that exocytosis elicited by $\mathrm{Ca}^{2+}$ currents smaller than $\sim 100 \mathrm{pA}$ occurs in two phases. However, we have never observed two discrete bouts of exocytosis. Furthermore, we found that the first phase of exocytosis involved only a fraction of the RRP, whereas the second phase primarily involved the remainder of the RRP. Only at delays longer than $300 \mathrm{msec}$ did we find evidence that vesicles from a reserve pool might also be released (Fig. $1 B, D$ ). When the $\mathrm{Ca}^{2+}$ current was larger than $\sim 140 \mathrm{pA}$, release of the RRP remained easily distinguished from release of the reserve pool. Indeed, previous capacitance measurements (Mennerick and Matthews, 1996; Sakaba et al., 1997; Gomis et al., 1999; Neves and Lagnado, 1999) and FM1-43 measurements (Neves and Lagnado, 1999) have demonstrated that release of the reserve pool occurs over a time scale of several hundred milliseconds, even when the $\mathrm{Ca}^{2+}$ current is large.

The use of the capacitance technique imposed an important limitation on the stimuli that we were able to use: they always involved a transition from a resting state at which all the $\mathrm{Ca}^{2+}$ channels were closed. Actually, the membrane potential of a depolarizing bipolar cell will often vary over a range in which the
$\mathrm{Ca}^{2+}$ current is active. To understand the operation of this synapse, it will therefore be necessary to understand how ongoing exocytosis is modulated by changes in membrane potential. Under these conditions, the size of the RRP will be dependent both on the rate of exocytosis and the rate at which it is supplied with new vesicles. Recent evidence indicates that refilling of the RRP is stimulated by $\mathrm{Ca}^{2+}$. Mennerick and Matthews (1996) found that EGTA inhibited the slow phase of exocytosis that followed release of the RRP and suggested that the translocation of vesicles might be rate-limiting during this process. However, they also found that EGTA did not inhibit the refilling of the RRP that occurred after stimulation and so concluded that a translocation process was not the primary means of refilling the RRP once $\mathrm{Ca}^{2+}$ channels had closed. In contrast, Gomis et al. (1999) found that inhibition of the slow phase of exocytosis by EGTA was correlated with reduced refilling of the RRP after stimulation. They provided evidence that the supply of vesicles for rapid exocytosis occurred through two distinct $\mathrm{Ca}^{2+}$-dependent steps, one regulating the movement of vesicles from a reserve pool to the RRP, and a second regulating the transfer of vesicles to the reserve pool. We therefore expect that the $\mathrm{Ca}^{2+}$-dependent translocation of vesicles to the plasma membrane will accelerate the supply of vesicles during stimulation, as well as recovery from synaptic depression after stimulation. The same may be expected of other ribbon synapses in which exocytosis is continuously modulated, such as those in auditory and vestibular hair cells (Furukawa et al., 1982; Parsons et al., 1994; Lenzi et al., 1999).

\section{REFERENCES}

Ashmore JF, Falk G (1980a) Responses of rod bipolar cells in the dark-adapted the retina of the dogfish. J Physiol (Lond) 300:115-150.

Ashmore JF, Falk G (1980b) The single-photon signal in rod bipolar cells of the dogfish retina. J Physiol (Lond) 300:151-166.

Attwell D, Borges S, Wu SM, Wilson M (1987) Signal clipping by the rod output synapse. Nature 328:522-524.

Augustine GJ, Charlton MP (1986) Calcium dependence of presynaptic calcium current and post-synaptic response at the squid giant synapse. J Physiol (Lond) 381:619-640.

Augustine GJ, Charlton MP, Smith SJ (1985) Calcium entry and transmitter release at voltage-clamped nerve terminals of squid. J Physiol (Lond) 369:163-181.

Barlow HB, Levick WR, Yoon M (1971) Response to single quanta of light in retinal ganglion cells of the cat. Vis Res Suppl 3:87-101.

Belgum JH, Copenhagen DR (1988) Synaptic transfer of rod signals to horizontal and bipolar cells in the retina of the toad (Bufo marinus). J Physiol (Lond) 396:225-245.

Bellingham MC, Walmsley B (1999) A novel presynaptic inhibitory mechanism underlies paired pulse depression at a fast central synapse. Neuron 23:159-170.

Betz WJ (1970) Depression of transmitter release at the neuromuscular junction of the frog. J Physiol (Lond) 206:629-644.

Blank PS, Cho M-S, Vogel SS, Kaplan D, Kang A, Malley J, Zimmerberg J (1998) Submaximal responses in calcium-triggered exocytosis by differences in the calcium sensitivity of individual secretory vesicles. J Gen Physiol 112:559-567.

Blight AR, Llinas R (1980) The non-impulsive stretch-receptor complex of the crab: a study of depolarization-release coupling at a tonic sensorimotor synapse. Philos Trans $\mathrm{R}$ Soc Lond B Biol Sci 290:219-276.

Burns ME, Augustine GJ (1995) Synaptic structure and function: dynamic organization yields architectural precision. Cell 83:187-194.

Burrone J, Lagnado L (1997) Electrical resonance and $\mathrm{Ca}^{2+}$ influx in the synaptic terminal of depolarizing bipolar cells from the goldfish retina. J Physiol (Lond) 505:571-584.

Crawford AC, Fettiplace R (1981) An electrical tuning mechanism in turtle cochlear hair cells. J Physiol (Lond) 312:377-412.

Del Castillo J, Katz B (1954) Quantal components of the end-plate potential. J Physiol (Lond) 124:560-573.

Dittman JS, Regehr WG (1998) Calcium dependence and recovery ki- 
netics of presynaptic depression at the climbing fiber to Purkinje cell synapse. J Neurosci 18:6147-6162.

Dodge Jr FA, Rahamimoff R (1967) Co-operative action of calcium ions in transmitter release at the neuromuscular junction. J Physiol (Lond) 193:419-432.

Dowling JE (1987) The retina: an approachable part of the brain. Cambridge, MA: Harvard UP.

Flock A, Russell I (1976) Inhibition by efferent nerve fibres: action on hair cells and afferent synaptic transmission in the lateral line canal organ of the burbot Lota lota. J Physiol (Lond) 257:45-62.

Furukawa T, Matsura S (1978) Adaptive rundown of excitatory postsynaptic potentials at synapses between hair-cells and afferent nerve fibres in goldfish. J Physiol (Lond) 276:193-209.

Furukawa T, Hayashida Y, Matsura S (1978) Quantal analysis of the excitatory post-synaptic potentials at synapses between hair-cells and eighth nerve fibres synapses in goldfish. J Physiol (Lond) 276:211-226.

Furukawa T, Kuno M, Matsura S (1982) Quantal analysis of a decremental response at hair-cell afferent fibre synapses in the goldfish sacculus. J Physiol (Lond) 322:181-195.

Gillis KD (1995) Techniques for membrane capacitance measurements. In: Single channel recording (Sakmann B, Neher E, eds), pp155-198. New York: Plenum.

Gomis A, Burrone J, Lagnado L (1999) Two actions of calcium regulate the supply of releasable vesicles at the ribbon synapse of retinal bipolar cells. J Neurosci 19:6309-6317.

Heidelberger R, Heinemann C, Neher E, Matthews G (1994) Calcium dependence of the rate of exocytosis in a synaptic terminal. Nature 371:513-515.

Hsu SF, Augustine GJ, Jackson MB (1996) Adaptation of $\mathrm{Ca}^{2+}$. triggered exocytosis in presynaptic terminals. Neuron 17:501-512.

Katz B, Miledi R (1967) A study of synaptic transmission in the absence of nerve impulses. J Physiol (Lond) 167:23-38.

Korn H, Faber DS, Burnod Y, Triller A (1984) Regulation of efficacy at a central synapse. J Neurosci 4:125-130.

Kusano K, Landau EM (1975) Depression and recovery of transmission at the squid giant synapse. J Physiol (Lond) 245:13-32.

Lagnado L (1998) Amacrine cells keep it short and sweet. Curr Biol 8:R598-R600.

Lagnado L, Gomis A, Job C (1996) Continuous vesicle cycling in the synaptic terminal of retinal bipolar cells. Neuron 17:957-967.

Lenzi D, Runyeon JW, Crum J, Ellisman MH, Roberts WM (1999) Synaptic vesicle populations in saccular hair cells reconstructed by electron tomography. J Neurosci 19:119-132.

Liley AW, North KAK (1953) An electrical investigation of effects of repetitive stimulation on mammalian neuromuscular junction. J Neurophysiol 16:509-527.

Llinas R, Steinberg IZ, Walton K (1981) Relationship between presynaptic calcium current and post synaptic potential in squid giant synapse. Biophys J 33:323-352.

Llinas R, Sugimori M, Simon SM (1982) Transmission by presynaptic spike-like depolarization in the squid giant synapse. Proc Natl Acad Sci USA 79:2415-2419.

Matsui K, Hosoi N, Tachibana M (1998) Excitatory synaptic transmission in the inner retina: paired recordings of bipolar cells and neurons of ganglion cell layer. J Neurosci 18:4500-4510.

Mennerick S, Matthews G (1996) Ultrafast exocytosis elicited by calcium current in synaptic terminals of retinal bipolar neurons. Neuron $17: 1241-1249$.
Mennerick S, Matthews G (1998) Rapid calcium-current kinetics in synaptic terminals of goldfish retinal bipolar neurons. Vis Neurosci 15:1051-1056.

Mintz IM, Sabatini BL, Regehr WG (1995) Calcium control of transmitter release at a cerebellar synapse. Neuron 15:675-688.

Neher E (1998) Vesicle pools and $\mathrm{Ca}^{2+}$ microdomains: new tools for understanding their roles in neurotransmitter release. Neuron 20:389-399.

Neher E, Marty A (1982) Discrete changes of cell membrane capacity observed under conditions of enhanced secretion in bovine adrenal chromaffin cells. Proc Natl Acad Sci USA 79:6712-6716.

Neves G, Lagnado L (1999) The kinetics of exocytosis and endocytosis in the synaptic terminal of goldfish retinal bipolar cells. J Physiol (Lond) 515:181-202.

Parsons TD, Lenzi D, Almers W, Roberts WM (1994) Calciumtriggered exocytosis and endocytosis in an isolated presynaptic cell: capacitance measurements in saccular hair cells. Neuron 13:875-883.

Roberts WM (1993) Spatial $\mathrm{Ca}^{2+}$ buffering in saccular hair cells. Nature 363:74-76.

Roska B, Nemeth E, Werblin FS (1998) Response to change is facilitated by a three-neuron disinhibitory pathway in the tiger salamander retina. J Neurosci 18:3451-3459.

Rouze NC, Schwartz EA (1998) Continuous and transient vesicle cycling at a ribbon synapse. J Neurosci 18:8614-8624.

Sakaba T, Tachibana M, Matsui K, Minami N (1997) Two components of transmitter release in retinal bipolar cells: exocytosis and mobilization of synaptic vesicles. Neurosci Res 27:357-370.

Stevens CF, Wesseling JF (1998) Activity-dependent modulation of the rate at which synaptic vesicles become available to undergo exocytosis. Neuron 21:415-424.

Tachibana M, Okada T, Arimura T, Kobayashi K, Piccolino M (1993) Dihydropyridine-sensitive calcium current mediates neurotransmitter release from bipolar cells of the goldfish retina. J Neurosci 13:2898-2909.

Triller A, Korn H (1982) Transmission at a central inhibitory synapse. III. Ultrastructure of physiologically identified and stained terminals. J Neurophysiol 48:708-736.

Tucker TR, Fettiplace R (1996) Monitoring calcium in turtle hair cells with a calcium-activated potassium channel. J Physiol (Lond) 494:613-626.

von Gersdorff H, Vardi E, Matthews G, Sterling P (1996) Evidence that vesicles on the synaptic ribbon of retinal bipolar neurons can be rapidly released. Neuron 16:1221-1227.

von Gersdorff H, Sakaba T, Berglund K, Tachibana M (1998) Submillisecond kinetics of glutamate release from a sensory synapse. Neuron 21:1177-1188.

Wang LY, Kaczmarek LK (1998) High-frequency firing helps replenish the readily releasable pool of synaptic vesicles. Nature 394:384-388.

Werblin FS, Dowling JE (1969) Organization of the inner retina of mudpuppy Necturus maculosus. II. Intracellular recording. J Neurophysiol 32:335-339.

Wu L-G, Borst JG (1999) The reduced release probability of releasable vesicles during recovery from short-term synaptic depression. Neuron 23:821-832.

Zucker RS (1989) Short-term synaptic plasticity. Annu Rev Neurosci $12: 13-31$ 